Ткаченко А. В., магістрант Київський наиіональний університет імені Тараса Шевченка м. Київ, Украӥна

DOI: https://doi.org/10.30525/978-9934-26-036-0-28

\title{
ФІНАНСОВИЙ ОБЛІК ЯК СУЧАСНИЙ АСПЕКТ ОРГАНІЗАЦІЇ СТРАТЕГІЧНОГО ФІНАНСОВОГО УПРАВЛІННЯ
}

Головною передумовою успішності діяльності підприємства $€$ деталізація прийнятих рішень та постійний контроль за виконанням бюджету підприємства. Реалізація поточних та оперативних планувань фінансування дає змогу ефективно управляти діяльністю підприємства.

Процес бюджетування планує та координує економічну діяльність; підвищує контроль за процесами підприємства; регулює виконання плану бюджету, який визначає ефективність роботи підприємства; рівномірно розпланований бюджет дозволяє запобігти виникненню проблем в майбутньому.

Фінансова інформація, рух коштів, рахунків та активів підприємства представляється системою бюджетування для прийняття ефективних управлінських рішень. Головною передумовою якого $\epsilon$ дотримання наукових вимог та розробка 2-3 видів бюджетів, визначення галузевої приналежності для врахування специфіки 
роботи підприємства та визначення шляхів покращення системи бюджетування [1].

Ефективність діяльності підприємства визначається прибутком, джерелами фінансових інвестицій, витратами, обсягом реалізації, рентабельністю та фінансовим станом підприємства. Передумовою ефективності є вдосконалення роботи фінансового менеджменту.

Головна мета розробки системи бюджетування є підвищення ефективності відповідальності за грошовими надходженнями від діяльності, доходами та витратами; підвищений контроль за обсягом виробництва, тощо.

Бюджет розробляють менеджери, головним із яких $є$ фінансовий менеджер, який відповідає за нього від появи і до його ліквідації. Професіоналізм фахівців визначає узгодженість роботи структурних підрозділів підприємства, розширення річного плану в господарській діяльності для усунення непередбачуваних змін у процесі діяльності, зменшення вірогідності допущення помилок.

Головними завданнями стратегічного фінансового управління підприємства є:

1) створення фінансового фонду;

2) передача ризиків страховому фонду;

3) оптимізація грошового обігу шляхом ефективного управління грошовими коштами;

4) оптимізація розмірів та складу активів підприємства;

5) забезпечення ефективності розподілу фінансових ресурсів підприємства;

6) ефективне управління політикою дивідендів, податків та амортизації.

Ефективність діяльності підприємства залежить від постійного фінансового вдосконалення зі складання фінансових планів, в яких враховується світовий досвід та реалізація новітніх технологій у власній сфері діяльності. Провідну роль виконує відділ фінансового менеджменту: аналізує та планує фінансову діяльність підприємства; складає фінансові стратегії, забезпечує 
висококваліфікованим персоналом; контролює реалізацію прийнятих рішень, тощо [2].

Для ефективної конкурентоспроможності з великими підприємствами, необхідно зменшити обсяги витрат на виробництво, але за умови уникнення зменшення ліквідності чи банкрутства та постійно контролювати використання ресурсів підприємства. Саме для цього потрібно запровадити процес бюджетування, який виконає ряд завдань: підвищить якість управління підприємством; врахує економічні наслідки в разі відхилень від планового бюджетування; виявить проблемні місця в управлінні підприємства.

Система бюджетування зменшує ризик втрати ринку на користь конкурентів, підвищує фінансову та економічну ефективність, створює автоматизовану систему розвитку власного бізнесу, адаптує підприємство на внутрішньому і зовнішньому ринках, формує більш професійний погляд та підхід для прийняття управлінських рішень.

Автоматизація бюджетування підвищує якість роботи під час виконання стратегій, оцінює ефективність виконаних дій протягом всього управлінського періоду бюджетування, поліпшує фінансові результати за допомогою управління прибутками та витратами та підвищує платоспроможність підприємства [3; 4].

Сучасним аспектом бюджетування $\epsilon$ можливість вносити зміни під час аналізу бюджету; загальна координація роботи підприємства; гнучкість управління; оперативне адаптування в новому колективі через зрозумілі поставлені цілі підприємства; підвищення якості розподілу ресурсів підприємства; підвищення якості документообігу; якісне та чітке розмежування бюджетів підрозділів; можливість аналізу діяльності підприємства в близькому майбутньому та зниження суб'єктивності в прийнятті рішень.

Отже, досягнення поставлених цілей в бюджетуванні набувають ті, хто має змогу контролювати та передбачувати можливі результати. Дотримуючись жорстокої фінансової дисципліни та мінімізації ризиків підприємство утримує рентабельність та 
ліквідність на заданому рівні, а також дотримуючись в ліміті витрат коштів задля контролю та уникненню нецільових платежів.

Новий підхід до вирішення поставлених цілей підприємства $є$ провідною ланкою прибуткової праці, належної конкурентоспроможності не тільки на вітчизняному ринку, а й на світовому. Слід зазначити, що це окрема ланка управління, контролю та планування бюджету, яка є економічно вигідною та невід'ємною в сучасних ринкових умовах реалізується через належний рівень знань головних етапів організації та методичних рекомендацій.

\section{Література:}

1. Власова Н.О., Круглова О.А., Безгінова Л.І. Фінанси підприємств : навчальний посібник. Київ, 2007. 271 с.

2. Роговий А.В. Фінансове планування як функція менеджменту підприємства. Науковий вісник ЧДІЕУ. Сер. Економіка. 2009. Вип. 2. С. 120-127.

3. Фінансовий менеджмент: теорія і практика / Балабонов Є.С. та ін. ; за ред. Є.С. Стоянової. Москва, 2003. 656 с.

4. Кузьмін О.С., Мельник О.Г. Бюджетування на підприємстві : навчальний посібник. Чернівці, 2008. 312 c. 